\title{
TANGLES OF CARE: Killing Goats to Save Tortoises on the Galápagos Islands
}

\author{
PAOLO BOCCI \\ Duke University \\ (D) http:// orcid.org/0000-0002-1181-8196
}

We are rather like a collective Noah, deciding with a biblical coldness which life forms will be able to accompany us on our new journey in the Ark.

- The Thematic Atlas of Project Isabela

"It wasn't pretty," Gil told me reticently, in an effort to keep to himself the images that had quickly surfaced in his mind. ${ }^{1}$ We were talking about dead goats, hundreds of thousands of them. A few years before, the world's largest mammal eradication had targeted goats on the Galápagos Islands, where he lives. A multimillion-dollar Global Environment Facility grant funded a multi-institutional effort involving the United Nations Development Program, the Galápagos National Park, the Charles Darwin Foundation, the Galápagos local government, and the Ecuadorian Ministry of Agriculture. Proyecto Isabela (PI) recruited thirty-eight hunters locally; weapons, veterinarians, hunting dogs, helicopters, and pilots came from all over the world. Together, they formed the most sophisticated and deadliest eradication assemblage ever attempted. From 2001 to 2006, PI targeted the mammal that, first introduced by pirates in the seventeenth century as a source of food, had denuded large swaths of vegetation and contributed to starvation among the endemic Galápagos tortoises: goats. Using helicopters as mobile shooting platforms, PI hunters killed more than two hundred thousand goats over an

CULTURAL ANTHROPOLOGY, Vol. 32, Issue 3, pp. 424-449, ISSN 0886-7356, online ISSN 1548-1360. (C) by the American Anthropological Association. Cultural Anthropology journal content published since 2014 is freely available to download, save, reproduce, and transmit for noncommercial, scholarly, and educational purposes. Reproduction and transmission of journal content for the above purposes should credit the author and original source. Use, reproduction, or distribution of journal content for commercial purposes requires additional permissions. DOI: 10.14506/ca32.3.08 
area of six hundred thousand hectares. Mangled by multiple shots, with their legs stiff in death, goats' carcasses lay on the steep gradients of volcanoes and the immense lava plains, rotting under the equatorial sun.

Although the park touted it as a successful project, Gil was not quite convinced. Despite the time that had elapsed, the images of PI-like the nightmares they inspired - were vivid. "It wasn't pretty, what shall I say? The way a lot of goats died wasn't clean. Goats run fast . . . lots of them got multiple shots, you see." He continued: "I’ve lived all my life here, I care about the islands [a mi me importan las islas]. But all these animals left to rot . . . not a nice spectacle, for sure!" Gil appeared almost embarrassed and preferred not to talk further. He had witnessed the outcomes of PI while on a trip to the Alcedo volcano on Isabela Island a few months after PI had ended. Piled on the slopes of the perfectly coned and active volcano, dead goats seemed to have unwillingly formed a funeral pyre of impossible size, a sacrifice that made Gil uncomfortable. He generally agrees with taking measures to protect endemic animals, but felt uneasy about PI. At last, he added: "They [the PI personnel] wanted to protect the Galápagos, I get that. But it looked like someone bombed the islands!”

To Gil, the consequences of PI eerily paralleled and compounded those of goats' overgrazing, adding a layer of gloom to a landscape that was already menacing the tortoises with extinction. Intended as a measure to restore ecosystems and the flourishing of life, PI did not appear so benign in his eyes. On the nearvertical inclines of Isabela's volcanoes, the consequences of saving tortoises - the goats' eradication - looked difficult to bear. Gil's impression of a bombed island echoes Anna Tsing's $(2015,3)$ contention that, in the time of unprecedented human impact on the earth, we live in "blasted landscapes" increasingly beyond the promise of recuperation. That PI's targeted areas looked like such a landscape, whose possibility of recovery had receded further and further away, was not only Gil's impression. Local residents protested against PI (though they could not stop it) and successfully blocked the ensuing proposal for an archipelago-wide eradication. As a compromise, the park conducted several campaigns aimed at reducing the number of goats on the inhabited islands. But hunters spared pregnant goats and young individuals, thus ensuring the survival of the goat population. Despite conservation's most cogent arguments and best efforts, goats still chew on the islands today - they just do so on fewer islands and in smaller areas. ${ }^{2}$ The project had unexpected ecological repercussions, as well as social ones. In the targeted areas invasive plants, rather than native ones, have grown back and taken over, and their eradication is deemed even more difficult than removing goats (Atkinson 
et al. 2012). Whether present or absent, goats have unraveled conservation measures on the Galápagos and, more broadly, stalled our imperative to respond caringly to the needs of other species.

In the face of the Anthropocene's environmental crisis, anthropologists, biologists, and philosophers are urging us to extend forms of care beyond our own species (Tsing 2015; Kohn 2014; Miller, Soulé, and Terborgh 2014; Haraway 2008; Latour 2013). Though the definition and the dating of the Anthropocene vary widely, less contentious seems to be the idea that, as Bruno Latour (2013) has proposed, the Anthropocene marks "the end of the human and the beginning of obligations" toward the more-than-human. Care suggests a mode of practical engagement that informs what scholars have called "obligation" (Stengers 2015, 62), "response-ability" (Barad 2012, 208), "flourishing" (Cuomo 1998, 78), or “astonishment” (Ingold 2011, 63) vis-à-vis other species and ecological assemblages. Caring practices might trace a path for "living on a damaged planet" (Tsing et al. 2017) and perhaps rendering the Anthropocene as short as possible (Haraway 2015). Yet what happens when measures of care to respond to the Anthropocene are not just invoked but actually taken? More to the point: what follows the commitment to save an endangered species?

Proyecto Isabela reacted locally against one of the Anthropocene's most prominent global features: extensive species loss largely due, for the first time in the earth's history, to anthropogenic causes. Iconic endemic animals of the Galápagos Islands (species that live nowhere else but there) such as the endangered giant tortoises have been the catalysts for conservationists' focused attention and intense forms of care (Santander et al. 2009). By eliminating goats to save endangered tortoises, PI's eradication followed from the care for tortoises. But can eradication itself constitute a form of care? Whether in the context of humans in hospitals or animals in a farm or zoo, care has not always been discussed as kind. Work in animal studies, the environmental humanities, and science and technology studies has shown that measures to keep endangered animals alive can be ambiguous and even violent (Chrulew 2011; Hennessy 2013; van Dooren 2014). Here, I enter an uncomfortable terrain to ask if care can kill. Care and eradication make an unstable and difficult marriage, given the habitual positive and negative connotations, respectively, of the two terms. Yet I argue that PI's practical mode of engagement with goats, based on persistence, creativity, and endless reconfigurations of technological and multispecies assemblages, is best understood as a form of care. Such care unfolded through an open, though unequal, dialogue 
between conservationists and goats, one that constantly attuned to the response of the other.

Scholars of humanitarian interventions have discussed how the moral imperative to save human lives often results in fraught practices of care. In instances such as conducting medical triage (Redfield 2013; Nguyen 2010) or rendering the suffering body legible to forms of state recognition (Ticktin 2011; Fassin and Rechtman 2009; Fassin 2012), the intent to do good likely produces uncomfortable situations, in which care "is accompanied . . . by practices of violence and containment" (Ticktin 2011, 6). Care in conservation is no exception: this essay unveils the continuity between the care for a loved species (Galápagos tortoises) and the lethal taking care of another one (goats). A "logic of care" (Mol 2008) has extended the practices of tending tortoises to learning about and intervening on goats, with the goal of the latter's extermination. This continuum unsettles the moral distinction between caring for a species, to which nature lovers and scholars alike subscribe comfortably, and killing (animal) others, which is instead generally condemned or ignored.

After situating PI ecologically and historically, this article delves into PI as a technoscientific intervention. The campaign altered goats' sociality as well as their very biology. It deployed radio-collared goats to track hiding peers and, for the first time in the world, engineered sterile female goats with an exceptionally long estrus that could attract fellow goats for longer periods and thus lead to a faster extermination. While many conservationists and ecologists had deemed its ambitious goals a chimeric fantasy, eradication in the targeted areas came about with the creation of an actual chimera (like the part-goat monster in Greek mythology). The article then turns to a discussion of how hunters, goats, and the general population on the Galápagos opposed the eradication campaign. As I will show, despite the project's technological sophistication, PI's downplaying of the role of goats in the ecological and social fabric of the Galápagos compromised its results. After a discussion of care's controversial nature, in the conclusion I offer further reflections on how care may help orient conservation and human life in the uncertain times of the Anthropocene.

A sign of human intervention of epic proportions, PI has indeed produced consequences, but not the ones intended. Opposite to its stated goal of separation, PI created, rather than severed, new ties between park wardens, scientists, locals, and goats. I explore this divergence ethnographically. ${ }^{3}$ Resisting an a priori philosophical posture against eradication, one that scholars in environmental humanities have taken (Rose 2008), this story shows the challenging ways in which we 
are implicated in animals' lives and deaths, and they in ours. The ways humans participate and intervene in environments transcend an axiological standpoint: even measures designed to respond against the Anthropocene can, in fact, expand its reach. Showing the world's most sophisticated eradication campaign to be a complex, contentious, and species-entangling practice of care illustrates this point. ${ }^{4}$

\section{OF HUMANS, GOATS, AND OTHER PROBLEMS}

The Galápagos National Park covers 97 percent of the archipelago, which straddles the equator seven hundred miles off the coast of mainland Ecuador. Though tourists have access to limited areas of the park in guided tours, local residents are confined to the remaining 3 percent. The human population of the archipelago has grown in the past fifty years from a few thousand to thirty thousand today, but residents continue to live in the circumscribed areas on four islands (Santa Cruz, San Cristóbal, Isabela, and Floreana) that the park established after its founding in 1959. Goats have cared little, however, about such important demarcations between nature and culture. They have been on the Galápagos throughout their human colonization, which began in the 1830s (Latorre 1999). In fact, goats preceded permanent human settlement, since pirates brought them to the islands as early as the seventeenth century (Dampier 1697). Goats have been pirates' food, eremites' companions, settlers' source of income, and a means of colonization. Goats have proved as successful as humans, if not better, at adapting to and thriving on the rugged Galápagos Islands. They benefit from a low metabolism, efficient digestion, an omnivorous diet, low water requirements, and a high reproductive rate. Goats' versatility in surviving in the Galápagos' harsh environments possesses an almost demonic quality: as incredulous settlers have observed, goats even drink salt water from the ocean (Latorre 1999).

Once introduced, they proliferated, even transgressing ecological barriers that ecologists considered impassable. In fact, crossing one such barrier provided the immediate justification for PI. The Perry Isthmus dramatically divides south Isabela, of a horizontal shape, from the center and the north, which are narrower and oblong. It stretches from east to west along a seven-mile-wide lava corridor between the Sierra Negra volcano in the south and Alcedo in the north. Devoid of vegetation, this isthmus consists of bare lava of the sharpest kind, which makes walking, human or animal, difficult if not impossible. Because of its impassability, the Perry Isthmus had created two tightly delimited ecological communities, 
technically termed ecological islands, that had evolved separately for millions of years (Warren et al. 2015).

For more than a century, goats had only lived in the south of Isabela, where there were also human settlements. But in 1966, a park ranger spotted a few goats north of the isthmus, on the flanks of Alcedo. Undisturbed, the population grew fast. In the early 1990s, park wardens who climbed the volcano were dismayed to observe goats' effects on vegetation. Before goats reached the volcano, wardens trekking on scorched slopes of pumice pebbles would pass through low, dry shrubs and gray Palo Santo trees. Closer to the caldera's rim, endemic Scalesia trees dotted the landscape that hosted Chelonoidis nigra vicina, the largest population of Galápagos tortoises in the wild (de Vries 1984). Nestled in Scalesia's branches, epiphytic ferns and orchids' leaves captured water particles in the air and condensed them on the ground. In these drip pools, tortoises drank and bathed. By the mid-nineties, all of this had disappeared. What a herpetologist described to me as the "impenetrable forest of Isabela's volcanoes" was gone completely. Goats' grazing had converted forest and shrubs into grassland. Lower humidity in the newly treeless landscape increased erosion triggered by the goats' stomping (Desender et al. 1999). Instead of trees and drip pools, there was a barren landscape and dust; instead of tortoises, goats.

From an estimated three thousand in 1992, the goat population in Alcedo was believed to have risen to between fifty thousand and one hundred thousand in 1996. An eradication campaign in 1996 killed ten thousand, but that number was regained in only one year (Cayot 1996). The nigra vicina subspecies had not died out, but it did face the concrete possibility of extinction. Goats were eating everything: all types of vegetation and even tree bark. After a trip to the volcano in 1992, a biologist remarked on the difference between tortoises' rather clumsy mechanics of eating and the precise, voracious methods of goats. For these "surefooted" (Merlen 1999, 5) mammals, eating had been sharpened by millennia of ferocious competition within their own species and against others. Goats would place their front legs on tree trunks or even tortoises' shells to reach higher leaves, in an accidental gesture of defiance and domination not unlike images of safari hunters posing on their trophies. Nigra vicina's shells had evolved with an arch above the neck to reach higher leaves, but goats hastily and unceremoniously dismissed this delicate line of evolution. Photos of goats on Alcedo mobilized international support for an eradication campaign. With eerie exactness, those images captured the unverbalized uneasiness about what appeared to be the ul- 
timate affront: goats' opportunistic bipedalism and resemblance to humans, alike in our tendencies to proliferate and trample nature.

While PI responded to the urgent matter of the near extinction of nigra vicina, it was but the latest use of a conservation tool, eradication, that has long been used to address ecologists' distress about the ecological changes that goats, other invasive species, and humans brought about on the islands. In the 1950s, the presence of alien species and people alike provoked shock and fear among scientists visiting the islands, which prompted the establishment of the Charles Darwin Foundation and the Galápagos National Park (Eibl-Eibesfeldt 1959). While cordoning off the vast majority of the islands proved more successful in controlling humans than goats, measures for eradicating the latter figure among the park's very first interventions. Later studies estimated that goats, whose population continued to grow, threatened to extinction around 60 percent of the Galápagos' 194 endemic plants (Cruz, Harcourt, and Lavoie 2007). Eradication seemed the only solution for an issue that would only worsen if left unaddressed. Against goats' inexorable proliferation, PI personnel concluded that only "eradication ensures a permanent solution with a single and final investment" (Cruz, Harcourt, and Lavoie 2007, 10). The park learned this the hard way. In the early 1960s, fishermen introduced two goats on Pinta, a deserted island northwest of the archipelago. Only a decade later, the single pair had become more than fortyone thousand goats (Campbell et al. 2004)!

In what follows, I describe PI as an intervention into the matter of life and the flesh of death. The project exploited and intervened in the goats' sociality, and even their very bodies, in profound ways. Goats were studied, modified biologically, lured, pitted against each other, chased, betrayed, poisoned, and shot. Hunting techniques were devised to counter the goats' altered behavior as the campaign progressed. Goats even became enrolled in the campaign for their own death. Sterilized and fitted with radio collars, hundreds of so-called Judas goats led hunters to goats who had survived earlier phases of eradication and were looking for a new herd. Furthermore, in a procedure never attempted before, PI personnel injected hormones into a sample of female goats to lengthen their estrus and render them attractive to male goats for longer periods. In effect, the campaign brought to life a new gender of goats to plunge their species into a localized annihilation.

Rather than constituting a single measure, eradication demanded continuous care and an unprecedented intervention into animals' bodies and sociality. Such forms of technoscientific care emerged in opposition to other practices of care 
for goats. Residents excluded from the tourism boom of the past two decades have most voiced their attachment to goats. Fishermen and farmers have traditionally lived with, and hunted, goats. Before tourists came, everyone on the islands was either a farmer or fisherman, or both. In the 1980s and 1990s, the nexus of tourism and conservation consolidated into a powerful political and economic regime (Ospina 2006; Quiroga 2009). Today, the Galápagos are praised as the last natural laboratory of evolution and an exclusive tourist destination (Grenier 2007; Larson 2001). At the same time, fishermen and farmers have suffered from a double marginalization. Compared to tourism, their economic activities have become less and less profitable; at the same time, new policies have increasingly restricted their activities in the name of conservation. Tourists have come to the islands in greater numbers every year, while mainland Ecuadorians have moved there to escape unemployment and poverty. Currently the islands' economy is growing at an impressive rate: if the archipelago were an independent state, its growth rate would rank among the highest in the world (Epler 2007). At the periphery of this circuit, fishermen and farmers feel like remnants of a past way of life on the islands. Their ties with goats are historical, cultural, and, in response to PI and the ensuing project of archipelago-wide eradication, they also became political.

\section{KILLING GOATS}

There are many deserving causes in Galápagos that urgently need attention, but few can equal the imminent destruction, not just of a species, but of the essential ambiance of the Galápagos Islands. I believe that it would be worth the clattering roar of helicopters, the chatter of guns, the movement of many people, and the endless investment of money to ensure the survival of this milieu Galapagueño before it is too late.

_Godfrey Merlen

The clatter of helicopters is what Doña Carmela remembers most about the eradication campaign: "For two years we had the noise [of helicopters] over our head . . . from the town to the park, to kill goats. Two years! It was like a war!” Proyecto Isabela used helicopters on the expanses of volcanic landscape, the basaltic soil too brittle and the areas too vast to be covered on foot. The Galápagos are volcanic islands with fierce sun, little water, and thick vegetation on rocky terrain or barren lava beds, depending on the altitude. Helicopters were but one aspect of the campaign. Mules carried hunters into the dense thickets on terrain 
above the arid coastal region. One hundred dogs from New Zealand and a few locally trained in the Galápagos accompanied hunters. Outfitted with special boots to protect against the heat and the sharp rocks, the dogs corralled goats into specific areas or found individual goats hiding in clefts. Semiautomatic shotguns, Benelli's M1 Super 90, came from Urbino, Italy. ${ }^{5}$ Targeted by a symphony of hunting techniques deployed in a concerted fashion, almost all goats were killed.

Estimates suggest that nearly 99 percent of the entire goat population on Santiago and 90 percent on Isabela were killed. The remaining population learned that humans, no longer allies in the islands' colonization, had become their enemies. Goats lost their innocence and became cautelosos (wary): hiding in inaccessible caves, they made themselves undetectable (Cruz, Harcourt, and Lavoie 2007). Yet even a small remnant of individuals holds the promise of regenerating the whole population and cannot be tolerated by an eradication campaign. On both islands, the surviving goats, now educated and suspicious, constituted the biggest problem, as they eluded standard hunting techniques. Goats, the hunted game, had learned the hunting game that helicopters, dogs, and humans were playing against them.

"In an effort to avoid educating animals, a systematic approach is needed," wrote the PI field assistant and veterinarian Karl Campbell. (To control masses, whether of people or goats, education should always be avoided.) Campbell proposed adding a further hunting technique to the human, canine, mule-assisted, and helicopter-based ones: hunters would capture hundreds of goats, fit them with radio collars, and release them onto Isabela's plains. These became the socalled Judas goats, the betrayers. ${ }^{6}$ Goats, as Aristotle (1995) wrote of humans, are social animals: their aversion to isolation would lead them to find their peers. Sending invisible beeps to a satellite and back to the island, goats would remotely tether PI hunters armed with directional antennas, first, and rifles, second. Once the goats were found, hunters would kill all except the collared goats. Two weeks later, hunters would return. Having just recovered from the previous massacre, the collared goats were expected to have found the strength once again to look for peers, to be gregarious, to hope for the future. On Isabela, this succession of shooting, allotted time for psychological recuperation, and more shooting went on for more than two years.

Unlike the biblical figure, Judas goats were not aware of the scheme in which they were protagonists, but the result was the same. Prevailing above everything, the herding instinct propelled eradication as inexorably as a natural force. Certainly some unforeseen complications arose, such as when a Judas goat 
would find other collared goats rather than unmonitored ones. In that event, all but one of the goats would be killed, the radio collars retrieved, and the survivor monitored to lead to further killings.

Judas goats proved helpful but not decisively so. Female Judas goats would get pregnant, lose their sociality, and thus stop leading PI hunters to other goats. Following the pregnant Judas goats, radio antennas would beep in a diminished cacophony. Helicopters would fly longer distances only to find fewer goats. In the midst of an eradication campaign, the goats' pregnancy meant a respite for their species in more than one sense: not only by procreating new life but also by slowing down death. Local extinction through Judas goats alone would occur too slowly and at too great a cost.

"I started then to think about how to improve this," Campbell explained to me in an interview. "What would be the perfect, ideal Judas goats?" He was thinking about a Judas goat that would search for, and be searched for, by other goats in perpetuity. What may sound like a Platonic quest for an ideal animal in fact unfolded in the realm of actual goats. Since veterinarians identified males searching for mates as the main driver of gregariousness, strategies to increase estrus became key. According to Campbell and his colleagues, the literature had established that "estrus duration may be increased by denying penile intromission during estrus" (Campbell et al. 2007, 14) —admittedly rather impractical in the wild. The other known cause of a longer estrus is nymphomania, "a poorly understood condition often diagnosed as cystic ovarian disease" (Campbell et al. 2007, 14). Campbell and his colleagues went on to reflect that "while nymphomaniac behavior would be desirable in Judas goat operations, it is unknown how to induce this condition" (Campbell et al. 2007, 14).

Putting aside the desire for an always desiring goat, Campbell resolved to capture female goats, terminate any pregnancy, sterilize them, and inject hormone implants. As a result of a new procedure, estrus would not last for the typical twenty days per year but for an astonishing one hundred eighty days. Since transportation to a veterinary camp would have been costly and time-consuming, Campbell operated on goats, one by one, on the scorched slopes of Isabela's volcanoes or the treeless volcanic plains of the lowland. Famous as "the natural laboratory of evolution” (Larson 2001, 125), the Galápagos became less a site for observing gradual changes over time and more a setting for artificial and deliberate variations on mattering: the making of a new goat. With a scalpel, anesthetics, and hormones, PI recombined the elements of female goats into oversexualized 
individuals, devoid of the ability to bear life but with an irresistible talent for delivering death.

The more their instinct for gregariousness prevailed over the landscape of death, the closer came eradication. The Judas goats, surpassing six hundred individuals, were thus divided: 33 percent fertile female, 33 percent male, and 33 percent sterile females with implanted hormones. Project personnel called the latter "Mata Haris," after the famous Dutch spy working in Indonesia during the First World War (Carrion et al. 2011, 3). Female spies are imagined to be attractive, after all, and definitely not entangled in the laborious, motherly business of pregnancy. Fusing the otherness and allure of tropical exotics and female deception, Mata Hari, the goats' third gender, performed 1.5 times better than the other Judas goats. With the creation and deployment of Mata Haris, PI personnel achieved what many experts believed impossible. Care (for the tortoises) killed the goats. Nowhere in the world had a mammal eradication of such magnitude ever been attempted (Carrion et al. 2011). If achieving it seemed to be a chimera, the key to PI's success lay in the careful forging of an actual chimera, a monstrous goat. ${ }^{7}$ The only way to realize a chimera was to make one.

\section{MATTERING CARE}

By looking at eradication as a continuous practice, my interpretation differs from both natural- and social-science approaches to this topic. The decision to execute Proyecto Isabela rested on the assumption that it was going to deliver a definitive solution to goats' ecological nuisance. Literature on the virtues of eradication of invasive species, like the species it promises to eliminate, proliferates in conservation biology. Invasion ecologists often portray eradication as "a costeffective and theoretically neat solution to prevent future or current impact of invasive species" (Wolff and Gardener 2012, 184). Eradication of one species' population results in fewer kills over time than do periodic population checks, thus offering both economic and moral advantages. As for the "theoretically neat" aspect, eradication ostensibly gets rid of the problem, the invasive species, once and for all: what could be neater than that?

Whether critical (Rose 2008) or in favor of eradication (Rolston 1999), work in the social sciences and humanities has implicitly shared this assumptionthat eradication always works. Building on seminal work in environmental history (Cronon 1983, 1996), scholars have argued that these interventions often hinge on a rigid temporal divide that separates nature (in the past, to be reverted to) and culture - the time when European settlers arrived (Brockington 2002; Low 
1999; van Dooren 2011). To be sure, desires to eliminate all forms of anthropogenic nature sustain conservation on the Galápagos too: a World Wildlife Foundation report (Bensted-Smith 2002) stated that conservation's goal is to revert ecosystems to their state prior to the islands' discovery in 1534. Environmental humanities scholars have mainly focused on the ethical implications, or lack thereof, of invasive-species management (Clark 2015; Ginn, Beisel, and Barua 2014; van Dooren 2011). They have argued that the labeling of undesired animals and the practices that target them, such as invasive species or humane killing and euthanasia, obscures the moral implications of conservation (Clark 2015; van Dooren 2011). Though I second this line of critique, I investigate eradication not only for what it stands for but also for what it does. Anthropologists and others have long criticized conservation measures for ignoring the ways local societies inscribe species, endemic or not, in their cosmologies, livelihood, and everyday life (Carrier and West 2009; Comaroff and Comaroff 2001; Moore 2012; West 2006). Yet they have made the same mistake when considering eradication as a self-contained intervention, failing to see how it reconfigures multispecies assemblages.

As a sustained and sophisticated intervention into an animal species, goat eradication on the Galápagos was unprecedented in magnitude, but not in typology of conservation care. The project's modulation of goats' bodies and sociality continued forms of intensive care for saving the Galápagos tortoises - the very species for which the goats were eliminated. Even before the establishment of the Galápagos National Park's Giant Tortoise Breeding Center in 1965, San Diego zookeepers experimented with a suite of practices to help Galápagos tortoises survive in captivity as early as in the 1930s. A San Diego curator urged keepers to "put tortoises to bed every evening to protect them from the cold and rain, since these animals are prone to respiratory ailments" (Hennessy 2013, 75). Other measures aimed at enhancing tortoises' fertility, copulation, and nesting behavior. Keepers opted for giving tortoises periods of sexual rest to increase fertility, while also experimenting with the best surface in the corrals to enable male tortoises to assume the "proper position to achieve copulation" (Hennessy 2013, 75).

On the Galápagos, the park's breeding center has raised more than four thousand tortoises and released them into the wild throughout fifty years of continuous improvements. This result has come about through meticulous targeting of tortoises' life such as sexual arousal, copulation, hatching, nesting, rearing, socialization, and diet. Conservation measures have not limited themselves to promote tortoises' healthy habits, but they have also intervened in the matter of 
tortoises. For instance, as tortoises' sex is temperature-dependent (the temperature of the egg determines the sex), the center has kept two-thirds of the eggs at $29.5^{\circ}$ Celsius (for females) and one-third at $28^{\circ}$ Celsius (for males), which the park believes to be the optimal ratio for promoting population growth (Hennessy 2013). In this context, PI's tinkering with goats' estrus hardly comes as a surprise.

On the Galápagos, as elsewhere, saving species on the brink of extinction requires great determination and continued effort (Hennessy 2013; van Dooren 2014). But so does the elimination of species responsible for an ecological threat. There is nothing inexorable about keeping one form of life alive or making another die. Both implicate humans, ethically and practically, in profound ways. Struggles to attain an invasive species' death are a continuation of those devoted to maintain alive an endangered species: both demand certain types of care. Eradication should evoke the image of continuously attending to an open wound in the tissues of living biota rather than that of swiftly performing a surgical incision.

Achieving mass death, in other words, is a laborious business. Adding to the profound moral considerations that systematic killing demands, scholars of genocide have also reflected on the intimate imbrication between extermination and the tools of modernity in the hands of nation-states: a powerful bureaucracy, the rational division of labor, and increased reliance on technical measures (Bauman 1989; Feldman and Seibel 2005; Wolf 1999). Anthropologists and others have examined the necessary, at times complicated work to design a group within a society as the part that must be excised and dispensed of (Hinton 2004; Semelin 2013; Fujii 2009). Here, I explore the contingent nature of animal mass killing by turning to its materiality. Eradication is a practical event that matters: whether it achieves its goal or not, it shapes society and nature, the matter of body politics and actual bodies too. Touted as a one-off, efficacious way to deal with invasive species, eradication instead requires sustained, sophisticated, and extraordinary efforts, and it is always rife with possibilities of failure.

In showing the continum between tending and caring for tortoises and intervening in and taking care of goats, I consequently question not only the assumption of care's benevolent means but also its goals. Anthropologists and science and technology studies scholars have reflected on forms of care that take place in hunting (Nadasdy 2007; Willerslev 2007), eradication (Nading 2014; Wanderer 2015), and animal mass killing (Mol, Moser, and Pols 2010). John Law has uncovered the moral dilemmas of U.K. farmers and veterinarians responding to the foot-and-mouth epidemic in the spring 2001. For Law, care for the suspected sick bovine was "a matter of good death" (Mol, Moser, and Pols 
2010, 61). Yet PI presents a different scenario: care was instrumental in scaling up the number of dead goats, rather than delivering a good death. Caring for the tortoises' survival translated and extended into technologies to make goats die: care's ability to reach and respond to, and to gather knowledge about and harness control over, the animal (see Giraud and Hollin 2016; Wanderer 2015) was subsumed under a logic of extermination. If care is the practical orientation that "attunes to the mortal bodies" (Mol 2008, 31), PI's care attuned to goats not to attend to their mortality but rather to exalt it, to make it thrive and contagiously proliferate.

\section{RESISTING CARE}

Eradication in the targeted areas finally occurred when all but the Judas goats had been eliminated. In the end, hunters were dismissed; the targeted mammals and even the introduced hunting dogs, killed; the helicopters and weapons repackaged in boxes and shipped out of the islands. The project seemingly concluded as planned: by effacing any trace of itself and allowing "nature" to take center stage. Photos circulated by the park showed the rapid regrowth of vegetation on the rim of Alcedo. These images were juxtaposed with ones taken before the advent of goats on the volcano. "I would like to say that we have done what the world believed was impossible! . . . Goats are part of Santiago's history," PI's director exulted (Cruz, Harcourt, and Lavoie 2007, 56). Once the history of their human introduction had been erased, goats gained the status of historical facts. Only their absence allowed goats to figure in the annals of Galápagos history. Goats' menace to endemic tortoises and ecosystems seemed nothing more than a parenthesis in the millions of years of the placid unfolding of natural evolution, while PI appeared to be a shining example of technocracy and human genius.

In fact, PI did not resolve matters as unambiguously as its supporters claimed. Resistance to goat eradication was expressed as opposition to the prospect of an archipelago-wide eradication but was already present during PI, as some of the hunters attempted to boycott it. The official publication about the campaign issued by the park proudly notes that 95 percent of the hunters were Galapagueños, anticipating the common complaint on the islands that jobs are outsourced (Cruz, Harcourt, and Lavoie 2007, 18). Yet among these hunters, even those most renowned for a longstanding collaboration with the park, uneasiness with eradication spread. Miguel, an elderly farmer, told me about his son, a park warden, who felt troubled about killing so many goats: "During the weekend he would come to my house and, with the kids away during the after- 
noon siesta, [his son would] say that he was tired of shooting goats. 'It's not why I chose to work in the park!' he would tell me.” Miguel's son added, “After weeks of walking and shooting, I got fed up. I loathed killing goats, especially in Santiago." Carlos, another hunter, talked to me with embarrassment about his experience with corralled goats in Santiago. His task was to shoot goats, one by one, for hours.

The dull repetition of killing, devoid of the fair rules of hunting and scaled up to the level of a massacre, understandably affected hunters. Yet there were other reasons for their defection. Because many hunters were local, their biographies had long been interwoven with rural land and the park's highlands, the tall grass of pasture, the narrow hunting trails monte adentro (in the mountains). "I was born and raised en la parte alta [in the highlands]," my friend Mauricio told me. "As a kid I learned to ride horseback; later, I looked after the cattle and started to hunt - goats, feral cattle, pigs, but mainly goats. I joined the [eradication] campaign for the money, but the idea bothered me that I will never be able to go with my kids on a friend's lancha [small boat] to Isabela and hunt goats for a weekend." While we were hiking through the impenetrable vegetation of the highlands, he once confided that during the goat population-control measures on Santa Cruz following PI, he and other hunters spared young goats and pregnant females. "We were OK with killing goats, but eradication seemed like too much! [Matar sí, pero erradicar nos pareció demasiado!]" he told me. But, he added, "it is something that we kept to ourselves." Other hunters revealed that even on Santiago they recorded some kills when in fact they had let goats go- until they were required to provide a piece of ear for each goat they killed as evidence.

As another complicating factor, PI took place during a period of tense relationships between the Galápagos National Park and fishermen. To voice their frustration against catch quotas set by the park, fishermen released goats on goatfree islands. A diving cruise once spotted a goat on Wolf, the most remote island of the archipelago, 120 miles from park headquarters on Santa Cruz. Two park rangers and a photographer sailed there. One of the two rangers eventually shot the goat. They sailed back, against the wind and current in rough seas, for a seemingly interminable forty-hour journey. "It [the goat] was a message," the ranger who shot the goat told me firmly. For this reason, PI officials decided to leave Judas goats on the targeted islands longer than planned to alert the park to potential introductions. If there were goats, Judas goats would reunite with them, sending their GPS location to the hunters. For fishermen, goats served as a message of protest against the park; in response, the park deployed Judas goats. Far 
from gone, goats became at once signified and signifier, message and messenger: a fishermen's symbol of rebellion and, for the park, a technology to further its policies.

Judas goats stayed on the islands for almost two years after PI had officially ended. Ironically, the project devoted to getting rid of goats intentionally left some on the ground. Because they were neutered, they could not increase the goat population. Yet their lingering presence symbolized a further departure from the image of eradication as a one-off, neat intervention. Surviving the most systematic and technologically advanced killing of mammals ever undertaken, Judas goats were left grazing in the wake of their own species' eradication, amid thousands of carcasses - sterile but useful.

The defiance of PI's aspirations was not only symbolic, nor human: during the campaign, goats' resistance added to human defection. James Scott (1985) has drawn attention to the minor modalities of protest in which oppressed people engage, whose significance, or even existence, long escaped historians' and often even their own oppressors' awareness. His book Weapons of the Weak masterfully describes the fragmented, uncoordinated yet diffuse ways in which peasants in a small Malaysian village expressed their dissent and acted against the status quo (cf. Hribal 2007; Wadiwel 2016). Proyecto Isabela's official documentation, amid the dazzle of graphs and data, did not include acts of protest, human or caprine. Yet goats resisted by learning, escaping, hiding, standing still. After all of the interviews and conversations I had about PI, the most poignant image with which I was left was that of immobile goats eluding hunters under the vegetation, the noise of helicopter blades hovering above and reverberating all the way to the coastal town of Puerto Villamil on Isabela. For animals of prodigious agility, the decision to stop came only after learning from the infelicitous fate of those that moved. It was, indeed, the little available to them to resist, or more likely to postpone, their elimination.

\section{CONTROVERSIAL CARE}

Care is active, it seeks to improve life.

-Annemarie Mol, Ingunn Moser, and Jeannette Pols

A way of caring over here could kill over there.

— Maria Puig de la Bellacasa 
By exploiting and altering goats' sociality and biology for the sake of their own local extinction while asking hunters to perform mass shootings, PI demands that we explore consequences of care-and, indeed, forms of care-that are uncomfortable. This departs from current anthropological understandings of multispecies care. In studies of public health campaigns against malaria or dengue, care informs the laborious, mundane, but necessary practices of everyday life in a more-than-human world. Attending to the lives of insects as dangerous vectors or plants as loved others, humans establish and maintain multispecies encounters through which to "explore what it entails . . . to be human" (Archambault 2016, 265). Two aspects of this type of multispecies care stand out: that it is about maintenance rather than change (Kelly and Lezaun 2014; Nading 2014; see also Carr 2015) and that it is positively affective (Archambault 2016; Nading 2014). In the context of dengue prevention in Nicaragua, Alex Nading (2012, 572-73; emphasis added) describes "caring for the cisterns, water barrels, and containers" where larvae of Aedes aegypti might infiltrate as satisfactory and even delightful: "Looking for mosquitoes is not just learning, it's fun."

Though this literature's concern with care as practice is relevant to my account of PI, taking care of unwanted species such as goats is, I contend, neither about maintenance nor pleasure. Proyecto Isabela aimed at profound ecological changes and not a continuation of the status quo. The messianic undertones of this article's opening epigraph illustrate PI's high stakes: to prevent extinction and restore ecologically degraded ecosystems. This justified even eradication's most contentious measures, such as leaving dead goats on the ground. Local residents proposed instead to recover and sell some of the meat. Project personnel refused, for they wanted (in their own words) to "close the loop" of a nutrient cycle: via plants, goats extracted nutrients from the soil; if removed, these minerals and organic components would have been subtracted from the ecosystems. Allowing the carcasses to rot offered the only possibility, if slow and distressing, for returning the nutrients to the soil.

Taking care of goats thus points to the contentiousness of care practices in conservation (cf. Martin, Myers, and Viseu 2015). Rather than "fun," eradication entailed guns. Recent work in animal studies has argued that conservation measures aimed at protecting endangered species are not always as irenic and uncontroversial as we have imagined - they can be ambiguous, coercive, and even violent (Kirksey 2012; Haraway 2011). Reflecting on practices for the insemination and breeding of endangered whooping cranes in the United States, Thom van Dooren $(2014,91)$ talks about forms of "violent care" whose goal of saving 
a species from extinction does not entitle us to disregard the ethical concerns these very practices raise (see also van Dooren 2011; Giraud and Hollin 2016). This contentiousness of caring for an endangered species is further amplified when, to save a species, conservation advocates plan for the local extermination of another one. Far from harmonious, care sheds light on the distressing aspects of conservation and, broadly, the complications that emerge when humans intervene in the lives of animals - whether by sustaining their life or laboring to thwart it (Shelton 2004).

\section{CAPRINE HUMANITIES}

"Goats have always been with us, they have helped us during all this time. I love raising goats . . . the park cannot exterminate that, for sure!” Rodrigo spoke to me with a grin showing disappointment and defiance at once, as he held the horn of one of his goats. The goats are corralled behind his farmhouse, only a few miles from the park. He told me that before eradication campaigns began, Puerto Villamil filled with hundreds of bleating goats when the cargo ship would come every other month. Corralled in the main square, goats were sold to the mainland en pie, alive. In those years, he would await with a mix of trepidation and anxiety the return of his father from a weeklong hunting trip. Appearing smaller than they are to the naked eye, the plains that contour the two large southern volcanoes outside Puerto Villamil are in fact immense and labyrinthine, with thick spinose bushes impeding the vista for those who venture onto them. Stories of people never returning still circulate. When Rodrigo grew strong enough, he joined his father in goat hunting. He still hunted as we spoke, his eyes scanning my body while asking me how I would feel about carrying on my shoulders and neck deskinned quarters of bloody, warm, dead goats. Rodrigo lives in the highlands, where subsistence rather than tourism still governs daily chores. "We have few . . . actually, no tourists here! [Turistas . . pocos. En verdad, no hay!]" he told me, oscillating his forearm back and forth longitudinally - the Ecuadorian sign for having a problem. "I keep hunting for as long as God and the Park want! [Sigo con la cacería hasta que Díos y el parque quieran!]”

My friend Gabriela, a farmer, would often mention goats as she reminisced about the Galápagos "before all this [tourist infrastructure] existed." When she was young, activities on the farm, not the regimen of a work week, marked the rhythms of everyday life. Days were spent planting crops, harvesting, riding horses to the beach, exploring the highlands, and hunting goats. "I don't understand all this rage against goats [No entiendo todo este furor contra los chivos]," she once told 
me, "while la gente abajo [people who live in the coastal town of Puerto Ayora and work in tourism] keep smuggling pet dogs onto the island!” Two decades ago, she cofounded a small tourism agency that managed a sailboat. She has always loved exploring the islands, and organizing excursions around the islands seemed like a great opportunity. But when tourism picked up, people became competitive and greedy. Her business partner changed too, and their relationship deteriorated. Gabriela quit without even claiming her share. Now the travel agency is among the many that benefit from the steady influx of tourism to the islands. "There is no awareness that we live in a national park [Ya no hay conciencia que estamos en un parque]. Meanwhile, I keep buying carne de chivo from hunters, to support them," she told me resolutely.

In the end, PI produced the opposite of its intended result. Counter to its goal, PI created new forms of human-goat sociality under the technoscientific practices of eradication, prompting locals to reaffirm and even create new modes of engagement with goats. Whether on farms or feral, goat meat serves the local market: seco de chivo (goat stew) is a delicious dish on the islands. Though there are fewer than before, hunters continue to venture into the highlands to search for goats. Still nowadays, a type of care for goats exists on trails through thorny bushes to the scorched volcanoes and back, drops of goats' blood falling intact on the dry soil.

\section{CONCLUSION}

In the wake of Proyecto Isabela, goats' diminished yet defiant presence unravels eradication's goal to neatly divide endemic and invasive nature. Eradication practices have paradoxically produced another instantiation of the ties that bind species together. In PI, care informed worlding interventions that drew together strands of biology and fibers of socialities to recombine them into something new. Resisting human attempts to untie them, multispecies knots forced ecological and anthropological thinking to slow down: to abandon long-used ideas about relationships and practices of separation between nature and society (Haraway 2008; Mitchell 2002; Myers 2015). Eradication and its consequences engendered responses to a situation for which there were no established norms, one that caused hesitation about each actor's obligation toward others (Barad 2012; Dave 2014; Haraway 2008; Stengers 2013).

Still, care does not only illuminate the thriving of multispecies life. The caring practices that informed Proyecto Isabela have added to and contrasted with alternative forms of multispecies care between residents and goats. Residents' 
inscription of goats in their ways of living on and caring for the Galápagos have competed with conservationists' care for tortoises. Scholarly attention to the more-than-human should therefore not solely map the connections between humans and other species but also account for the contentious nature of multispecies assemblages. The geographers Paul Robbins and Sarah Moore (2013) have suggested that scientists, caught between contradictory fears of imposing human values onto landscapes while not responding to ecological degradation with adequate urgency, should address the political aspects of conservation, invasion ecology, and restoration. But political positioning alone runs the risk of staying at the level of enunciation and forgetting about the unexpected ways in which matter changes, the geometry of multispecies webs varies, and emerging assemblages overlap and rival each other. In its emphasis on practice, the analytic lens of care brings into focus the consequences of a political commitment such as that of saving an endangered species from extinction. This essay has shown how multispecies caring practices are plural and contested. Complicating any political position vis-à-vis eradication, whether in favor of or against it, attention to care helps scholars and practitioners alike move past the rigid determination of success or failure for conservation measures toward an open, continuous commitment to the flourishing of multispecies life in the uncertain times of the Anthropocene.

\section{ABSTRACT}

If calls to care for other species multiply in a time of global and local environmental crisis, this article demonstrates that caring practices are not always as benevolent or irenic as imagined. To save endemic tortoises from the menace of extinction, Proyecto Isabela killed more than two hundred thousand goats on the Galapagos Islands in the largest mammal eradication campaign in the world. While anthropologists have looked at human engagements with unwanted species as habitual and even pleasurable, I discuss an exceptional intervention that was ethically inflected toward saving an endemic species, yet also controversial and distressing. Exploring eradication's biological, ecological, and political implications and discussing opposing practices of care for goats among residents, I move past the recognition that humans live in a multispecies world and point to the contentious nature of living with nonhuman others. I go on to argue that realizing competing forms of care may help conservation measures - and, indeed, life in the Anthropocene - to move beyond the logic of success and failure toward an open-ended commitment to the more-than-human. [care; Anthropocene; multispecies assemblages; conservation; Galápagos Islands] 


\section{NOTES}

Acknowledgments Thanks to Neel Ahuja, Anne Allison, Mara Buchbinder, Dietra Buxton, Jocelyn Chua, Rudi Colloredo-Mansfeld, Amelia Fiske, Vincent Joos, Townsend Middleton, Peter Redfield, Kailey Rocker, Jennifer Shaw, Harris Solomon, Gigi Taylor, and Margaret Wiener for taking the time to read this article and improve it. Thanks to the two anonymous reviewers for their helpful comments and to Dominic Boyer for his smooth guidance during the final phases of publication. Fieldwork was funded by the Social Science Research Council and the Institute for the Study of the Americas; the Center for Galapagos Studies helped me with my research visa.

1. As a measure to ensure anonymity, all personal names of Galápagos residents have been changed.

2. The project targeted goats in northern Isabela, Santiago, and Pinta Islands. Small populations of goats still live on Santa Cruz, San Cristobal, and southern Isabela.

3. Engaging in multispecies ethnography, this essay's topic differs from anthropology's traditional unit of inquiry, anthropos, to investigate the lives of humans and animals and to reflect on the fate of both. In their foundational article on multispecies ethnography, Eben Kirksey and Stefan Helmreich (2010) offer four criteria by which multispecies ethnography is anthropological: relatedness, exchange, governmentality, and signification. Though carrying the specific imprint of Michel Foucault's scholarship, their explanation clarifies the anthropological relevance of all strands of multispecies ethnography.

4. This article is based on the author's conversations with Galápagos residents and PI personnel during fieldwork on the Galápagos in 2010, 2012, and 2013-2014.

5. Urbino was one of the prime centers of fifteenth-century European humanism and home of the Duke of Montefeltro, the influential promoter of artists such as Raphael, after whom Benelli named one of its signature guns. Arguably, PI's use of Benelli's arms repurposed the late Renaissance aesthetics of natura morta (still life; literally, dead nature). On the Galápagos, though, stillness resulted from lethal technology rather than artistic sublimation.

6. A Spanish church contacted the park to protest against the use of biblical names. On Judas goats, see Taylor and Katahira 1988.

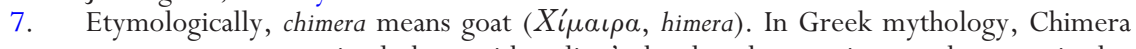
was a monstrous animal that, with a lion's head and a caprine trunk, terrorized a province in south Turkey. The hero Bellerophon who finally killed it was aided by Pegasus, a winged horse (Kilinski 2013, 194) — a precursor of PI's helicopters? For other chimeric uses of animals in contemporary technoscientific practices, see Etches 1997.

\section{REFERENCES}

Archambault, Julie Soleil

2016 "Taking Love Seriously in Human-Plant Relations in Mozambique: Toward an Anthropology of Affective Encounters." Cultural Anthropology 31, no. 2: 244 71. https://doi.org/10.14506/ca31.2.05.

Aristotle

1995 Politics. Translated by Ernest Barker. New York: Oxford University Press.

Atkinson, Rachel, Mark Gardener, Grant Harper, and Victor Carrion

2012 "Fifty Years of Eradication as a Conservation Tool in Galápagos: What Are the Limits?" In The Role of Science for Conservation, edited by Matthias Wolff and Mark Gardener, 183-98. New York: Routledge.

Barad, Karen

2012 “On Touching - The Inhuman that Therefore I Am.” differences 23, no. 3: 20623. https://doi.org/10.1215/10407391-1892943. 
Bauman, Zygmunt

1989 Modernity and the Holocaust. Ithaca, N.Y.: Cornell University Press.

Bensted-Smith, Robert, ed.

2002 “A Biodiversity Vision for the Galápagos Islands." Report for the World Wildlife Fund and the Charles Darwin Foundation.

Brockington, Dan

2002 Fortress Conservation: The Preservation of the Mkomazi Game Reserve, Tanzania. Bloomington: Indiana University Press.

Campbell, Karl J., Greg S. Baxter, Peter J. Murray, Bruce E. Coblentz, and C. Josh

Donlan

2007 "Development of a Prolonged Estrus Effect for Use in Judas Goats." Applied Animal Behavior Science 102, nos. 1-2: 12-23. https://doi.org/10.1016/ j.applanim.2006.03.003.

Campbell, Karl, C. Josh Donlan, Felipe Cruz, and Victor Carrion

2004 "Eradication of Feral Goats Capra hircus from Pinta Island, Galápagos, Ecuador.” Oryx 38, no. 3: 328-33. https://doi.org/10.1017/S0030605304000572.

Carr, E. Summerson

2015 "Occupation Bedbug: Or, the Urgency and Agency of Professional Pragmatism." Cultural Anthropology 30, no. 2: 257-85. https://doi.org/10.14506/ca30.2.08.

Carrier, James G., and Paige West, eds.

2009 Virtualism, Governance, and Practice: Vision and Execution in Environmental Conservation. New York: Berghahn.

Carrion, Victor, C. Josh Donlan, Karl J. Campbell, Christian Lavoie, and Felipe Cruz

2011 "Archipelago-Wide Island Restoration in the Galápagos Islands: Reducing Costs of Invasive Mammal Eradication Programs and Reinvasion Risk." PLoS ONE 6 (5): e18835. https://doi.org/10.1371/journal.pone.0018835.

Cayot, Linda J.

1996 “Alcedo Update.” Noticias de Galápagos, no. 57: 3-4.

Chrulew, Matthew

2011 "Managing Love and Death at the Zoo: The Biopolitics of Endangered Species Preservation." Australian Humanities Review, no. 50: 137-57. http://www. australianhumanitiesreview.org/archive/Issue-May-2011/chrulew.html.

Clark, Jonathan L.

2015 “Uncharismatic Invasives.” Environmental Humanities 6, no. 1: 29-52. https:// doi.org/10.1215/22011919-3615889.

Comaroff, Jean, and John L. Comaroff

2001 "Naturing the Nation: Aliens, Apocalypse, and the Postcolonial State." Social Identities 7, no. 2: 233-65. https://doi.org/10.1080/13504630120065301.

Cronon, William

1983 Changes in the Land: Indians, Colonists, and the Ecology of New England. New York: Hill and Wang.

1996 "The Trouble with Wilderness: Or, Getting Back to the Wrong Nature." Environmental History 1, no. 1: 7-28. https://doi.org/10.2307/3985059.

Cruz, Felipe, Sylvia Harcourt, and Christian Lavoie, eds.

2007 "The Thematic Atlas of Project Isabela: An Illustrative Document Describing, Step-by-Step, the Biggest Successful Goat Eradication Project on the Galapagos Islands, 1998-2006." Puerto Ayora, Galápagos, Ecuador: Charles Darwin Foundation.

Cuomo, Chris J.

1998 Feminism and Ecological Communities: An Ethic of Flourishing. New York: Routledge.

Dampier, William

1697 A New Voyage Round the World. London: James Knapton.

Dave, Naisargi N.

2014 "Witness: Humans, Animals, and the Politics of Becoming." Cultural Anthropology 29, no. 3: 433-56. https://doi.org/10.14506/ca29.3.01. 
Desender, Konjev, Leon Baert, Jean-Pierre Maelfait, and Peter Verdyck

1999 "Conservation on Volcán Alcedo (Galápagos): Terrestrial Invertebrates and the Impact of Introduced Feral Goats.” Biological Conservation 87, no. 3: 303-310. de Vries, Tjitte https://doi.org/10.1016/S0006-3207(98)00078-0.

1984 “The Giant Tortoises: A Natural History Disturbed by Man.” In Key Environments: Galapagos, edited by Rogert Perry, 145-56. Oxford: Pergamon.

Eibl-Eibesfeldt, Irenäus

1959 "Survey on the Galapagos Islands." Report. Paris: UNESCO.

Epler, Bruce

2007 "Tourism, the Economy, Population Growth, and Conservation in Galapagos."

Report. Puerto Ayora, Galápagos, Ecuador: Charles Darwin Foundation.

https://www.galapagos.org/conservation/conservation/

Etches, Robert J. conservationchallenges/tourism-growth.

1997 "Chimeras and Transgenics: From Greek Mythology to Poultry Breeding."

Fassin, Didier Presentation. Champaign, Ill.: Poultry Science Association.

2012 Humanitarian Reason: A Moral History of the Present. Berkeley: University of California Press.

Fassin, Didier, and Richard Rechtman

2009 The Empire of Trauma: An Inquiry into the Condition of Victimhood. Translated by Rachel Gomme. Princeton, N.J.: Princeton University Press.

Feldman, Gerald D., and Wolfgang Seibel, eds.

2005 Networks of Nazi Persecution: Bureaucracy, Business, and the Organization of the Holocaust. New York: Berghahn.

Fujii, Lee Ann

2009 Killing Neighbors: Webs of Violence in Rwanda. Ithaca, N.Y.: Cornell University Press.

Ginn, Franklin, Uli Beisel, and Maan Barua

2014 "Flourishing with Awkward Creatures: Togetherness, Vulnerability, Killing." Environmental Humanities 4, no. 1: 113-23. https://doi.org/10.1215/ 22011919-3614953.

Giraud, Eva, and Gregory Hollin

2016 "Care, Laboratory Beagles, and Affective Utopia." Theory, Culture, and Society 33, no. 4: 27-49. https://doi.org/10.1177/0263276415619685.

Grenier, Christophe

2007 Conservación contra natura: las islas Galápagos. Quito: Institut Français d'Études Andines. https://doi.org/10.4000/books.ifea.5519.

Haraway, Donna J.

2008 When Species Meet. Minneapolis: University of Minnesota Press.

2011 "Speculative Fabulations for Technoculture's Generations: Taking Care of Unexpected Country." Australian Humanities Review, no. 50: 95-118. http:// www.australianhumanitiesreview.org/archive/Issue-May-2011/haraway.html.

2015 “Anthropocene, Capitalocene, Plantationocene, Chthulucene: Making Kin.” Environmental Humanities 6, no. 1: 159-65. https://doi.org/10.1215/ 22011919-3615934.

Hennessy, Elizabeth

2013 "Producing 'Prehistoric' Life: Conservation Breeding and the Remaking of Wildlife Genealogies.” Geoforum 49: 71-80. https://doi.org/10.1016/ j.geoforum.2013.05.012.

Hinton, Alexander Laban

2004 Why Did They Kill? Cambodia in the Shadow of Genocide. Berkeley: University of California Press. 
Hribal, Jason C.

2007 "Animals, Agency, and Class: Writing the History of Animals from Below." Human Ecology Review 14, no. 1: 101-12. http://www.humanecologyreview.

Ingold, Tim org/141.htm.

2011 Being Alive: Essays on Movement, Knowledge and Description. New York: Routledge. Kelly, Ann H., and Javier Lezaun

2014 "Urban Mosquitoes, Situational Publics, and the Pursuit of Interspecies Separation in Dar es Salaam.” American Ethnologist 41, no. 2: 368-83. https://

Kilinski, Karl doi.org/10.1111/amet.12081.

2013 Greek Myth and Western Art: The Presence of the Past. New York: Cambridge University Press.

Kirksey, Eben

2012 "Living with Parasites in Palo Verde National Park.” Environmental Humanities 1, no. 1: 23-55. https://doi.org/10.1215/22011919-3609958.

Kirksey, S. Eben, and Stefan Helmreich

2010 “The Emergence of Multispecies Ethnography.” Cultural Anthropology 25, no. 4: 545-76. https://doi.org/10.1111/j.1548-1360.2010.01069.x.

Kohn, Eduardo

2014 "Toward an Ethical Practice in the Anthropocene." HAU 4, no. 1: 459-64. https: / / doi.org/10.14318/hau4.1.028.

Larson, Edward J.

2001 Evolution's Workshop: God and Science on the Galápagos Islands. New York: Basic Books.

Latorre, Octavio

1999 El hombre en las Islas Encantadas: la historia humana de Galápagos. Quito: FUNDACYT.

Latour, Bruno

2013 "The Anthropocene and the Destruction of the Image of the Globe." Gifford Lectures on Natural Theology, University of Edinburgh, February 25. http:// www.giffordlectures.org/file/prof-bruno-latour-anthropocene-and-destructionimage-globe.

Law, John

2010 "Care and Killing: Tensions in Veterinary Practice." In Care in Practice: On Tinkering in Clinics, Homes and Farms, edited by Annemarie Mol, Ingunn Moser, and Jeannette Pols, 57-69. Bielefeld, Germany: Transcript Verlag.

Low, Tim

1999 Feral Future: The Untold Story of Australia's Exotic Invaders. Chicago: University of Chicago Press.

Martin, Aryn, Natasha Myers, and Ana Viseu

2015 "The Politics of Care in Technoscience." Social Studies of Science 45, no. 5: 62541. https://doi.org/10.1177/0306312715602073.

Merlen, Godfrey

1999 Restoring the Tortoise Dynasty: The Decline and Recovery of the Galapagos Giant Tortoise. Quito: Charles Darwin Foundation.

Miller, B., M. E. Soulé, and J. Terborgh

2014 “New Conservation’ or Surrender to Development?” Animal Conservation 17, no.

Mitchell, Timothy 6: 509-15. https://doi.org/10.1111/acv.12127.

2002 Rule of Experts: Egypt, Techno-Politics, Modernity. Berkeley: University of California Press.

Mol, Annemarie

2008 The Logic of Care: Health and the Problem of Patient Choice. New York: Routledge. Originally published in 2006. 
Mol, Annemarie, Ingunn Moser, and Jeannette Pols, eds.

2010 Care in Practice: On Tinkering in Clinics, Homes and Farms. Bielefeld, Germany: Transcript Verlag.

Moore, Amelia

2012 "The Aquatic Invaders: Marine Management Figuring Fishermen, Fisheries, and Lionfish in the Bahamas." Cultural Anthropology 27, no. 4: 667-88. https:// doi.org/10.1111/j.1548-1360.2012.01166.x.

Myers, Natasha

2015 "Conversations on Plant Sensing: Notes from the Field." NatureCulture, no. 3:

Nadasdy, Paul

35-66. http://natureculture.sakura.ne.jp/03-acting-with-non-human-entities.

2007 "The Gift in the Animal: The Ontology of Hunting and Human-Animal Sociality." American Ethnologist 34, no. 1: 25-43. https://doi.org/10.1525/

Nading, Alex M. ae.2007.34.1.25.

2012 "Dengue Mosquitoes Are Single Mothers: Biopolitics Meets Ecological Aesthetics in Nicaraguan Community Health Work.” Cultural Anthropology 27, no. 4: 57296. https://doi.org/10.1111/j.1548-1360.2012.01162.x.

2014 Mosquito Trails: Ecology, Health, and the Politics of Entanglement. Berkeley: University of California Press.

Nguyen, Vinh-Kim

2010 The Republic of Therapy: Triage and Sovereignty in West Africa's Time of AIDS. Durham, N.C.: Duke University Press.

Ospina, Pablo

2006 Galápagos, naturaleza y sociedad: actores sociales y conflictos ambientales en las islas Galápagos. Quito: Corporación Editora Nacional.

Quiroga, Diego

2009 "Crafting Nature: The Galapagos and the Making and Unmaking of a 'Natural Laboratory.'” Journal of Political Ecology 16: 123-40. http://jpe.library. arizona.edu/Volume16/Volume_16.html.

Redfield, Peter

2013 Life in Crisis: The Ethical Journey of Doctors Without Borders. Berkeley: University of California Press.

Robbins, Paul, and Sarah A. Moore

2013 "Ecological Anxiety Disorder: Diagnosing the Politics of the Anthropocene." cultural geographies 20, no. 1: 3-19. https://doi.org/10.1177/ 1474474012469887.

Rolston, Holmes, III

1999 "Respect for Life: Counting what Singer Finds of No Account." In Singer and His Critics, edited by Dale Jamieson, 247-68. Malden, Mass.: Blackwell.

Rose, Deborah Bird

2008 “Judas Work: Four Modes of Sorrow.” Environmental Philosophy 5, no. 2: 51-66. https://doi.org/10.5840/envirophil2008528.

Santander, Tatiana, José Antonio González Novoa, Washington Tapia, Eddy Araujo, and

Carlos Montes del Olmo

2009 Tendencias de la investigación científica en Galápagos y sus implicaciones para el manejo

Scott, James C. del archipiélago. Quito: Parque Nacional de Galápagos.

1985 Weapons of the Weak: Everyday Forms of Peasant Resistance. New Haven, Conn.: Yale

Semelin, Jacques University Press.

2013 Purify and Destroy: The Political Uses of Massacre and Genocide. Translated by Cynthia Schoch. New York: Columbia University Press. Originally published in 2005. 
Shelton, Jo-Anne

2004 “Killing Animals That Don't Fit In: Moral Dimensions of Habitat Restoration." Between the Species 13, no. 4. http://digitalcommons.calpoly.edu/bts/vol13/ iss4.

Stengers, Isabelle

2013 "Introductory Notes on an Ecology of Practices." Cultural Studies Review 11, no. 1: 183-96. https://doi.org/10.5130/csr.v11i1.3459.

2015 In Catastrophic Times: Resisting the Coming Barbarism. Translated by Andrew Goffey. London: Open Humanities Press/Meson Press. Originally published in 2009. http://www.openhumanitiespress.org/books/titles/in-catastrophic-times.

Taylor, Dan, and Larry Katahira

1988 "Radio Telemetry as an Aid in Eradicating Remnant Feral Goats." Wildlife Society Bulletin 16, no. 3: 297-99. http://www.jstor.org/stable/3782103.

\section{Ticktin, Miriam I.}

2011 Casualties of Care: Immigration and the Politics of Humanitarianism in France. Berkeley: University of California Press.

Tsing, Anna Lowenhaupt

2015 The Mushroom at the End of the World: On the Possibility of Life in Capitalist Ruins. Princeton, N.J.: Princeton University Press.

Tsing, Anna Lowenhaupt, Heather Anne Swanson, Elaine Gan, and Nils Bubandt, eds.

2017 Arts of Living on a Damaged Planet: Ghosts and Monsters of the Anthropocene. Minneapolis: University of Minnesota Press.

van Dooren, Thom

2011 "Invasive Species in Penguin Worlds: An Ethical Taxonomy of Killing for Conservation." Conservation and Society 9, no. 4: 286-98. https://doi.org/ 10.4103/0972-4923.92140.

2014 Flight Ways: Life and Loss at the Edge of Extinction. New York: Columbia University Press.

Wadiwel, Dinesh Joseph

2016 "Fish and Pain: The Politics of Doubt." Commentary on "Why Fish Do Not Feel Pain,” by Brian Key. Animal Sentience 1, no. 3. http:/ / animalstudiesrepository.org/ animsent/vol1/iss3/31.

Wanderer, Emily Mannix

2015 "Biologies of Betrayal: Judas Goats and Sacrificial Mice on the Margins of Mexico.” BioSocieties 10, no. 1: 1-23. https://doi.org/10.1057/biosoc.2014. 13.

Warren, Ben H., et al.

2015 "Islands as Model Systems in Ecology and Evolution: Prospects Fifty Years after MacArthur-Wilson.” Ecology Letters 18, no. 2: 200-217. https://doi.org/10. 1111 /ele.12398.

West, Paige

2006 Conservation Is Our Government Now: The Politics of Ecology in Papua New Guinea. Durham, N.C.: Duke University Press.

Willerslev, Rane

2007 Soul Hunters: Hunting, Animism, and Personhood among the Siberian Yukaghirs. Berkeley: University of California Press.

Wolf, Eric R.

1999 Envisioning Power: Ideologies of Dominance and Crisis. Berkeley: University of California Press.

Wolff, Matthias, and Mark Gardener, eds.

2012 The Role of Science for Conservation. New York: Routledge. 